\title{
PENGARUH MODAL PSIKOLOGIS TERHADAP PERILAKU PRODUKTIF PADA KARYAWAN BAGIAN PRODUKSI PT. SLJ GLOBAL TBK DAN KARAKTERISTIK PEKERJAAN SEBAGAI MODERATOR THE EFFECT OF PSYCHOLOGICAL CAPITAL ON PRODUCTIVE BEHAVIOR IN EMPLOYEES OF THE PRODUCTION PART OF PT. GLOBAL TBK SLJ WITH JOB CHARACTERISTICS AS A MODERATOR \\ Maymanah $^{(1)}$ Silvia Eka Mariskha ${ }^{(2)}$ Siti Khumaidatul Umaroh ${ }^{(3)}$
}

Fakultas Psikologi, Universitas 17 Agustus 1945 Samarinda ${ }^{(1)}$ Fakultas Psikologi, Universitas 17 Agustus 1945 Samarinda ${ }^{(2)}$ Fakultas Psikologi, Universitas 17 Agustus 1945 Samarinda $^{(3)}$

Email: maymamay10@gmail.com ${ }^{(1)}$ mariskha87@ gmail.com ${ }^{(2)}$ sitikhumaidatulumaroh@yahoo.co.id ${ }^{(3)}$

\begin{abstract}
Abstrak : Penelitian ini bertujuan untuk membuktikan secara empiris apakah terdapat pengaruh modal psikologis terhadap perilaku produktif dan apakah karakteristik pekerjaan memoderasi pengaruh modal psikologis terhadap perilaku produktif. Penelitian ini terdiri dari tiga variabel yaitu perilaku produktif sebagai variabel dependen, modal psikologis sebagai variabel independen dan karakteristik pekerjaan sebagai variabel moderator. Teknik penentuan sampel dengan menggunakan random sampling. Sampel dalam penelitian ini adalah karyawan bagian produksi di PT. SLJ Global Tbk sebanyak 153 orang. Teknik analisa data yang digunakan dalam penelitian ini adalah metode Moderated Regression Analysis (MRA). Hasil penelitian pertama menunjukkan terdapat pengaruh yang signifikan antara modal psikologis (X) terhadap perilaku produktif (Y) dengan nilai $\mathrm{R}$ pada uji hipotesis pertama sebesar 0,597 yang berarti bahwa modal psikologis memiliki nilai korelasi terhadap perilaku produktif. Hasil penelitian kedua menunjukkan bahwa karakteristik pekerjaan (Z) tidak memoderasi pengaruh antara modal psikologis $(\mathrm{X})$ terhadap perilaku produktif $(\mathrm{Y})$ dengan nilai korelasi 0,600, namun nilai Adjusted R Square hanya sebesar 0,347 yang artinya tingkat persentase pengaruh menurun menjadi $34,7 \%$ dari nilai persentase sebelum adanya karakteristik pekerjaan.
\end{abstract}

Kata Kunci: Modal Psikologis, Perilaku Produktif, Karakteristik Pekerjaan

\begin{abstract}
This study aims to prove empirically whether there is an influence of psychological capital on productive behavior and whether job characteristics moderate the influence of psychological capital on productive behavior. This study consists of three variables, namely productive behavior as the dependent variable, psychological capital as an independent variable and job characteristics as a moderator variable. Sampling technique using random sampling. The sample in this study is a production department employee at PT. SLJ Global Tbk as many as 153 people. The data analysis technique used in this study is the Moderated Regression Analysis (MRA) method. The results of the first study indicate that there is a significant influence between psychological capital $(X)$ on productive behavior $(Y)$ with the value of $R$ on the first hypothesis test of 0.597 which means that psychological capital has a correlation value to productive behaviour. The results of the second study showed that job characteristics $(Z)$ did not moderate the influence of psychological capital $(X)$ on productive behavior $(Y)$ with a correlation value of 0.600, but the Adjusted $R$ Square value was only 0.347 which means the percentage effect level decreased to $34.7 \%$ of percentage value before the job characteristics.
\end{abstract}

Keywords: Psychological Capital, Productive Behavior, Job Characteristics

\section{PENDAHULUAN}

Produktivitas sering dikaitkan dengan cara dan sistem yang efisien, sehingga proses produksi berlangsung tepat waktu dan dengan demikian tidak diperlukan kerja lembur dengan segala implikasinya, terutama implikasi biaya. Tentunya hal tersebut merupakan hal yang logis dan tepat apabila peningkatan produktivitas dijadikan salah satu sasaran jangka panjang perusahaan dalam langkah pelaksanaan strateginya. Namun berapapun banyaknya 
rencana yang dibuat oleh pemimpin perusahaan, tanpa didukung oleh karyawan dalam melaksanakan pekerjaan, maka tujuan yang hendak dicapai tidak akan terwujud. Upaya meningkatkan produktivitas perusahaan perlu dilakukan melalui karyawan dari perusahaan, karena justru pada diri mereka terjadi proses perilaku yang mengarah pada hasil akhir dalam bentuk produktivitas. Sasaran peningkatan produktivitas dalam hal ini adalah perilaku karyawan yang mengarah pada produktivitas itu sendiri dan bukan pada produktivitas organisasi secara umum (Suhariadi, 2005).

Masalah produktivitas tenaga kerja hampir dialami oleh semua perusahaan besar maupun yang tergolong sedang berkembang. Beberapa perusahaan di Indonesia sendiri telah melakukan berbagai upaya untuk meningkatkan produktivitas tenaga kerjanya agar dapat membantu perusahaan dalam mencapai tujuannya. Seperti yang telah dilakukan oleh TelkomGroup dimana berbagai cara telah dilakukan manajemen agar memberikan kenyamanan bagi karyawannya dalam meniti karir, diantaranya pemberian insentif, serta program-program pengembangan kompetensi yang membuat karyawan senantiasa termotivasi untuk menghasilkan kinerja terbaiknya. Keseluruhan langkah tersebut sangat membantu TelkomGroup dalam mempertahankan produktivitas serta kenyamanan kerja sehingga karyawan termotivasi untuk senantiasa memberikan yang terbaik agar TelkomGroup dapat mempertahankan kesuksesannya (Selular.ID, 2018). Berbagai upaya yang dilakukan oleh perusahaan dalam meningkatkan produktivitasnya secara umum lebih mengutamakan pada pengkondisian lingkungan kerja. Hal tersebut dilakukan untuk menyentuh sisi psikologis karyawan agar termotivasi bekerja secara lebih produktif. Namun hal itu saja tidak cukup untuk meningkatkan produktivitas, perlu memunculkan perilaku produktif dari karyawan. Pengkondisian lingkungan dalam bentuk apapun apabila tidak menghasilkan perilaku produktif, tidak akan memberikan kontribusi apapun terhadap perusahaan dan terhadap karyawan itu sendiri (Suhariadi, 2001).

Tidak mudah memunculkan perilaku produktif pada diri karyawan. Banyak faktor yang menyebabkan munculnya perilaku produktif, Suhariadi (2002) menjelaskan ada dua faktor yang mempengaruhi perilaku produktif yaitu faktor lingkungan (eksternal) dan faktor individu (internal). Menurut suhariadi (2002) perilaku produktif pada dasarnya terbentuk dari dua jenis perilaku secara bersamaan, yaitu perilaku uang efektif dan perilaku yang efisien. Perilaku yang efektif adalah perilaku yang menghasilkan kinerja yang sesuai dengan rencana, sedangkan perilaku efisien adalah perilaku yang mampu memanfaatkan sumber daya dengan baik sehingga menghasilkan kinerja yang bernilai jauh lebih tinggi dari sumber daya yang digunakan (Suhariadi, 2002).

Penelitian yang dilakukan oleh Sumarti (2012) menyebutkan bahwa perilaku produktif dipengaruhi oleh pemberian kompensasi. Sedangkan dalam penelitian yang dilakukan oleh Kurt Lewin (dalam Ardhiatama, 2013) menyebutkan faktor eksternal lainnya yang menyebabkan perilaku produktif adalah gaya kepemimpinan dan iklim organisasi. Selain halhal tersebut yang merupakan faktor eksternal terdapat pula faktor internal sebagai faktor yang mempengaruhi perilaku produktif yaitu motivasi, kepuasan kerja dan juga psikologis karyawan. Menurut Suhariadi (2016) faktor psikologis karyawan yang lebih banyak berperan sebagai konsekuensi dari tingkat produktivitas yang dicapai. Pengertian tersebut memberikan pemahaman bahwa produktivitas karyawan dapat dipengaruhi oleh faktor psikologis, artinya jika karyawan memiliki modal psikologis yang baik maka akan memunculkan perilaku kerja yang positif pula yaitu perilaku produktif pada karyawan. Modal psikologis merupakan struktur yang positif baik secara pribadi maupun tingkat organisasi dan meningkatkan kinerja manusia (Luthan, 2002). Modal psikologis ini sebagai hal positif psikologis yang dimiliki oleh setiap karyawan yang berguna dalam membantu perkembangan karyawan dan yang ditandai oleh: keyakinan (self-efficacy) untuk menyelesaikan pekerjaan, memiliki pengharapan positif (optimism) tentang keberhasilan saat ini dan di masa yang akan datang, tekun dalam berharap (hope) untuk berhasil, dan tabah dalam menghadapi berbagai permasalahan (resiliency) hingga mencapai sukses (Luthan, Youssef dan Avolio, 2007).

Selain faktor internal terdapat pula faktor eksternal yang dapat mempengaruhi secara langsung maupun secara tidak langsung terhadap perilaku produktif karyawan. Kajian literatur mengenai hal tersebut disebutkan dalam penelitian yang telah dilakukan oleh Sutaji (2014) yang menyebutkan bahwa terbentuknya motivasi dan perilaku produktif karyawan 
dipengaruhi secara langsung oleh iklim organisasi, namun hal lain menyebutkan bahwa perilaku produktif dipengaruhi secara tidak langsung oleh karakteristik pekerjaan sebagai faktor eksternal (Suhariadi, 2002).

William dan Hazer (dalam Bangun, 2006) mengatakan bahwa karakteristik pekerjaan merupakan faktor utama yang ditemukan secara konsisten dalam pembentukan kepuasan kerja sehingga pekerja tersebut akan lebih produktif. Review literature yang dilakukan oleh Hendryadi (2015) menyebutkan identifikasi karakteristik pekerjaan yang tepat terkait pekerjaan tertentu memiliki peran penting dengan berbagai sikap karyawan di dalam perusahaan. Karakteristik pekerjaan yang dikembangkan oleh Hackman dan Oldham (1980) melalui model karakterisatik pekerjaan, yang memberikan sebuah penjelasan bagaimana struktur kerja mempengaruhi perilaku karyawan dan sikap mereka terhadap kondisi kerja. Melalui dimensi inti spesifik keterampilan, identitas tugas, arti tugas, otonomi dan umpan balik Hackman dan Oldham (1980) menjelaskan bagaimana dimensi tersebut dapat mempengaruhi hasil kerja karyawan.

Salah satu perusahaan yang menginginkan peningkatan produktivitas pada tenaga kerjanya adalah PT. SLJ Global Tbk. Saat ini tingkat produktivitas karyawan PT. SLJ Global Tbk di bagian produksi masih belum mencapai target yang diinginkan perusahaan sehingga hal itu membuktikan bahwa karyawan bagian produksi kurang produktif. Menurut data research and development PT. SLJ Global Tbk pada tahun 2018, semua bagian yang terlibat dalam proses produksi tidak mencapai target yang diinginkan oleh perusahaan baik yang bekerja menggunakan mesin maupun yang manual. Salah satunya adalah bagian Repair Core pencapaian targetnya hanya $55 \%$ pada shif A dan $42 \%$ pada shif B di periode minggu pertama bulan April 2018. Selanjutnya pada mingguminggu berikutnya pun mengalami hal yang sama yaitu tidak tercapainya target perusahaan sebesar 100 pcs/jam yang disebabkan berbagai hal diantaranya kurang maksimalnya waktu efektif kerja karyawan, tingkat absensi yang tergolong cukup tinggi terutama dihari libur (Minggu/Libur Nasional).

Penelitian Luthans dan Avolio (2005), yang menyimpulkan bahwa modal psikologis keseluruhan para karyawan di China memiliki hubungan positif dengan kinerja yang dinilai oleh para supervisornya. Hal serupa juga terjadi pada penelitian Luthans, Avolio dan Norman (2006) yang menyimpulkan bahwa terdapat hubungan yang positif antara modal psikologis secara keseluruhan dengan kinerja karyawan. Hasil penelitian terdahulu yang dilakukan oleh Liwarto dan Kurniawan (2015) menyatakan bawah modal psikologis secara keseluruhan dari karyawan

berhubungan positif dan signifikan dengan kinerja karyawan.Perilaku produktif menuntut orang untuk melakukan upaya apa saja asalkan tujuan organisasi tercapai, bahkan kalau perlu peraturan (SOP/standard operating procedure) dilanggar demi mencapai tujuan organisasi/perusahaan. Menurut McNeese-Smith yang dikutip dari Suhariadi (2016) menyatakan bahwa pola perilaku efektif (produktif) tersebut menuntut orang untuk fleksibel dan tidak terpaku pada aturan-aturan serta tidak harus sesuai dengan aturan. Hal ini dapat dilakukan dengan karakteristik pekerjaan otonomi yaitu tingkat dimana karyawan diberikan kebebasan dalam menentukan jadwal maupun prosedur pekerjaannya sendiri sehingga tujuan dapat tercapai dengan baik.

\section{METODE PENELITIAN}

Variabel dalam penelitian ini adalah modal psikologis dan perilaku produktif dengan karakteristik pekerjaan sebagai moderator. Modal psikologi merupakan sebuah kapasitas psikologis individu yang berkembang dengan karakteristik yaitu efikasi diri, optimisme, harapan dan resiliensi. Perilaku produktif merupakan perilaku yang menghasilkan produktivitas maksimal dengan pemakaian sumber daya dan biaya yang minimal untuk mengetahui seberapa jauh perilaku tersebut mampu memberikan kontribusi positif pada pencapaian kinerja yang didasari oleh perilaku efektif dan perilaku efisien. Karakteristik pekerjaan didefinisikan sebagai sifat-sifat pekerjaan yang memiliki fungsi motivasi bagi para karyawan agar bisa melakukan pekerjaanya menjadi lebih baik melalui lima dimensi yaitu keanekaragaman keterampilan, identitas tugas, signifikansi tugas, otonomi dan umpan balik.

Penelitian ini dilakukan pada karyawan dibagian produksi PT. SLJ Global Tbk yang berjumlah 153 orang. Alat ukur penelitian menggunakan skala Psychological Capital Questionnaire (PCQ) yang disusun oleh Luthan (2007) dan diadaptasi oleh peneliti, skala perilaku produktif disusun oleh Suhariadi (2001) 
dan dikembangkan oleh peneliti, dan skala Job Diagnostic Survey (JDS) yang disusun Hackman dan Oldham (1980) dan di adaptasi oleh peneliti.

Analisa data menggunakan analisis moderated atau MRA (Moderated Regression Analysis) dengan bantuan SPSS versi 21. Taraf signifikansi yang digunakan dalam penelitian ini sebesar $5 \%$.

\section{HASIL}

Berdasarkan hasil pengujian terhadap hipotesis pertama dalam penelitian ini yaitu pengaruh modal psikologis terhadap perilaku produktif, yang di uji menggunakan Moderate Regresi Analisys (MRA) maka diperoleh hasil bahwa dengan nilai $\mathrm{R}$ pada uji hipotesis pertama sebesar 0,597 yang berarti bahwa modal psikologis memiliki nilai korelasi terhadap perilaku produktif dengan nilai Adjusted $\mathrm{R}$ Square sebesar 0,352 yang artinya bahwa modal psikologis berpengaruh signifikan $0,000(\mathrm{p}<$ $0,05)$ terhadap perilaku produktif sebesar $35,2 \%$. Hasil pengujian hipoesis kedua dalam penelitian ini yaitu pengaruh modal psikologis terhadap perilaku produktif dengan karakteristik pekerjaan sebagai moderator ditolak, dikarenakan nilai Adjusted R Square hanya sebesar 0,347 yang artinya tingkat persentase pengaruh menurun menjadi $34,7 \%$ dari nilai persentase sebelumnya sebelum adanya karakteristik pekerjaan.

Berdasarkan hasil tersebut, maka dapat dketahui bahwa "hipotesis pertama diterima namun hipotesis kedua ditolak". Sehingga dapat dikatakan bahwa ada pengaruh modal psikologis terhadap perilaku produktif dan keberadaan karakteristik pekerjaan (sebagai variabel moderator) tidak dapat memperkuat atau meningkatkan pengaruh modal psikologis terhadap perilaku produktif.

\section{DISKUSI}

Melalui proses analisa data seperti yang diuraikan di atas, maka didapatkan hasil bahwa terdapat pengaruh antara modal psikologis terhadap perilaku produktif. Modal psikologis sebagai kondisi psikologis yang positif diharapkan akan menimbulkan perilaku yang positif pula. Hal tersebut sejalan dengan penelitian Luthans, Avolio, Norman (2006) yang menyimpulkan bahwa terdapat hubungan yang positif antara modal psikologis secara keseluruhan dengan kinerja karyawan. Hal serupa juga terjadi pada penelitian terdahulu yang dilakukan oleh Liwarto dan Kurniawan (2015) menyatakan bawah modal psikologis secara keseluruhan dari karyawan berhubungan positif dan signifikan dengan kinerja karyawan.

Hubungan dimensi modal psikologis lainnya dengan kinerja adalah hope (harapan), karyawan mampu memiliki harapan tinggi melakukan pekerjaan sesuai target yang ditetapkan. Namun dari aspek yang lain seperti perubahan pola bekerja ketika mengalami kesulitan, menciptakan kreasi dan inovasi baru, serta menganggap diri sebagai orang sukses, mereka masih perlu ditingkatkan dengan pelatihan yang mampu membangkitkan semangat mereka. Hal ini diungkapkan dalam penelitian Hendarman yang dikutip oleh Liwarto dan Kurniawan (2015) yang menyimpulkan bahwa terdapat hubungan antara Hope dengan Kinerja karyawan pada sektor industri jasa disebabkan karena berfokus pada pelayanan terhadap konsumen, para karyawan berusaha memuaskan pelanggan, mengurangi keluhan, pimpinan di perusahaan jasa ini memberikan target baik untuk menyelesaikan masalah maupun mencari pelanggan baru, sehingga hal ini memotivasi karyawan untuk selalu melakukan inovasi baru. Hasil penelitian ini juga mendukung jurnal.

Penelitian yang dilakukan oleh Luthans, Avolio (2005) yang menyimpulkan terdapat hubungan positif antara efikasi diri (self efficacy) dengan kinerja signifikan, namun hubungan di antara keduanya sangat rendah. Karyawan yang memiliki efikasi diri yakin bagaimana cara meningkatkan motivasi mereka. Mereka memilih tugas yang menantang untuk memperluas kemampuan kinerja mereka dan memotivasi diri mereka untuk melawan kendala yang dihadapi saat bekerja mencapai tujuan.

Dimensi lain yaitu optimism (sikap positif) juga turut mempengaruhi, ketika para karyawan memiliki semangat positif dan akan siap dalam menghadapi situasi sulit mereka akan kuat secara fisik dan mental, akan cenderung merasa nyaman dan berpikir dengan kepala dingin. Karyawan mampu menghadapi ketidakpastian yang terjadi di perusahaan, tetap optimis mengharapkan hasil kerja yang terbaik, dan berpikir positif ketika ada sesuatu yang terjadi pada pekerjaan. Kedua hal ini mampu memperkuat kinerja karyawan. Perilaku efektif (perilaku produktif) disebabkan oleh daya tahan akan kegagalan secara positif, artinya karyawan akan melakukan upaya apa saja asalkan tujuan 
organisasi/perusahaan dapat tercapai (Suhariadi, 2001), hal tersebut dapat teratasi jika karyawan memiliki modal psikologis yang baik terutama reliensi (daya tahan) dan harapan untuk bangkit dari kegagalan.

Hasil penelitian ini menunjukkan bahwa modal psikologis secara menyuluruh mempengaruhi perilaku produktif karyawan PT. SLJ Global dibagian produksi dikarenakan ketika para karyawan memiliki modal psikologis yang tinggi maka perilaku produktif yang diharapkan akan muncul, modal psikologis yang terdiri dari efikasi diri, harapan, resiliens dan optimis sangat berperan penting dalam membentuk motivasi dan kepuasan karyawan sehingga berdampak pada meningkatkan perilaku produktif dalam bekerja.

Karyawan yang memiliki ketahanan atau resiliensi yang tinggi cenderung mampu untuk bangkit dari kesulitan atau proses depresi sehingga memungkinkan orang tersebut untuk menjadi optimis dalam situasi yang luar biasa. Disisi lain, optimis juga akan menemukan halhal baik dari kesengsaraan dan kesulitan dalam hidup. Selain itu karyawan yang memiliki harapan berhasil akan diwujudkan dalam suatu upaya tetap bertahan pada sasaran dan jika perlu mencari jalan lain agar sasaran dapat dicapai. Karyawan dengan efikasi diri yang tinggi juga akan berupaya meraih keberhasilan dalam menyelesaikan tugas-tugasnya karena ketekunan dan keuletan dalam berusaha demi meraih prestasi. Keempat modal psikologis ini diyakini mampu berkontribusi positif dalam diri karyawan sehingga karyawan tersebut dapat bekerja dengan optimal.

Hasil proses analisa diatas juga didapatkan hasil bahwa pengaruh modal psikologis terhadap perilaku produktif tidak dapat meningkat dengan adanya variabel karakteristik pekerjaan sebagai moderator. Hal tersebut disebabkan perilaku kerja karyawan makin efektif manakala tidak mempunyai banyak macam keterampilan dalam menjalankan tugas. Secara tegas dinyatakan dimuka bahwa efektivitas perilaku kerja bisa dicapai manakala ada rasa optimis, efikasi diri dan harapan serta resiliensi dalam menyelesaikan pekerjaan dari awal hingga akhir dari orang yang bersangkutan. Menyelesaikan pekerjaan dari awal hingga akhir dilakukan secara tekun dan terus menerus berusaha memperbaiki hasil kerjanya, sehingga karyawan tersebut harus konsisten dan ajeg pola kerjanya agar tujuan organisasi tercapai. Untuk itu macam keterampilan yang dibutuhkan makin sedikit, karena yang dibutuhkan adalah konsistensi untuk terus menerus melakukan pekerjaan dengan tanpa harus mempertanyakan kembali kenapa begini dan kenapa begitu. Bila seseorang memiliki keanekaragaman ketrampilan yang tinggi maka semakin sering orang tersebut mencoba cara yang lain dan mempertanyakan kembali apa benar metode yang tengah dikerjakan, apa tidak sebaiknya dicari metode yang lain. Sehingga individu malah sering bertanya dan tidak mensegerakan tindakan guna mencapai tujuan perusahaan.

Demikian pula pada karyawan yang mempunyai level kepangkatan lebih rendah, perilaku kerjanya cenderung menunjukan kepatuhan, tidak suka mendebat, dan tugas dijalankan sesuai dengan apa yang telah diperintahkan oleh pimpinan. Pimpinan atau perusahaan sejak awal akan memberikan petunjuk dan pedoman kerja pada mereka, untuk selanjutnya karyawan yang mempunyai level kepangkatan lebih rendah akan menjalankan tugas sesuai dengan petunjuk tanpa harus (bahkan mungkin tidak berani) mempertanyakan lagi alasan-alasan tertentu tentang pelaksanaan tugas tersebut. Para karyawan yang punya level kepangkatan lebih rendah ini tidak punya bargaining power untuk melawan aturan yang ditetapkan sehingga perilaku sehari-hari yang ditampakan adalah perilaku patuh, tunduk, dan taat pada ketetapan kediplinan kerja. Hal ini tentunya menghambat perilaku kerja karyawan karena tidak dapat memutuskan sikap yang harus diambil sekalipun karyawan tersebut memiliki efikasi diri yang baik.

Selain tingkat kepangkatan yang rendah, terdapat juga alasan lain yaitu tingkat pendidikan yang rendah. Karyawan mampu melakukan pekerjaan yang efektif dan efisien dalam memperbaiki hasil kerjanya tentunya didasari oleh dasar-dasar pengetahuan tentang pekerjaan yang dijalani, kondisi ini ternyata mampu dijalankan oleh individu yang mempunyai tingkat pendidikan lebih tinggi. Makin rendah tingkat pendidikan seseorang makin sulit memahami kondisi pekerjaan sehingga diduga sulit melakukan kedisiplinan dalam melakukan penyempurnaan kerja.

Terakhir adalah bahwa seseorang yang memiliki daya tahan kegagalan tinggi akan makin efektif perilaku kerjanya manakala orang tersebut kurang diberikan umpan balik. Seseorang yang punya daya tahan kegagalan yang tinggi adalah orang-orang yang setiap hari selalu diterpa dan didera masalah-masalah yang 
menuntutnya segera dipecahkan, manakala mengalami kegagalan akan diusahakan untuk dicoba lagi agar lebih berhasil dari yang awal. Pada karyawan-karyawan tersebut, apabila diberi umpan balik malah menurunkan efektifitas perilakunya karena dirasa umpan balik yang diberikan malah mengganggu usaha pencapaian tujuan. Umpan balik bagi mereka tidak dianggap sebagai pemicu atau pengarah kepada kondisi yang benar namun umpan balik dianggap sebagai pengganggu dari upaya pencapaian tujuan dari masing-masing anggota organisasi.

Sejalan dengan penelitian Suhariadi (2002) yang menyebutkan beberapa dimensi dari karakteritik pekerjaan tidak memoderasi semangat terhadap perilaku efektif dan perilaku efisien, namun dalam penelitian ini diketahui bahwa karakteritik pekerjaan secara menyeluruh tidak memoderasi pengaruh modal psikologis terhadap perilaku pekerjaan.

\section{KESIMPULAN}

Berdasarkan penelitian yang telah dilakukan, maka kesimpulan dari penelitian ini adalah sebagai berikut:

Pertama, Diketahui bahwa variabel modal psikologis $(\mathrm{X})$ berpengaruh terhadap perilaku produktif (Y) karyawan bagian produksi PT. SLJ Global Tbk dengan nilai korelasi R 0,597 dan Adjusted R Square 0,352 dengan signifikasi $0,000(\mathrm{p}<0,05)$. Maka terdapat pengaruh yang signifikan antara modal psikologis terhadap perilaku produktif sebesar $35,2 \%$.

Kedua, Diketahui bahwa variabel karakteristik pekerjaan (Z) menurunkan pengaruh antara modal psikologis (X) terhadap perilaku produktif (Y) karyawan bagian produksi PT. SLJ Global Tbk dengan Adjusted R Square sebesar 0,347 atau jika dipersentasekan hanya sebesar $34,7 \%$. Menurunnya tingkat persentase pengaruh modal psikologis terhadap perilaku produktif membuktikan bahwa variabel karakteristik pekerjaan tidak dapat memoderasi pengaruh modal psikologis terhadap perilaku produktif.

\section{SARAN}

Berdasarkan penelitian yang telah dilakukan, maka saran yang dapat diberikan adalah sebagai berikut:

Pertama, Bagi Perusahaan
Disarankan kepada perusahaan PT. SLJ Global Tbk agar memberikan pengembangan kepada para karyawan seperti pengembangan modal psikologis maupun pelatihan keterampilan agar karyawan dapat memiliki modal psikologis yang baik serta menambah keterampilan guna tercapainya target perusahaan.

Kedua, Bagi Peneliti Selanjutnya

Disarankan menggunakan masing-masing dimensi sebagai variabel independent agar mendapatkan hasil yang lebih detail dan akurat, serta dapat memperluas jumlah sampel yang dipakai sehingga dapat memperkaya hasil penelitian.

\section{DAFTAR PUSTAKA}

Ardhiatama, D \& Suhariadi. F. (2013). Hubungan Antara persepsi Kepemimpinan Transformasional dengan Perilaku Produktif Karyawan di PT. BPR Taman Dhana Sidoarjo. Jurnal Psikologi Industri dan Organisasi. Vol. 2 No. 01

Bangun, W. (2006) Pengaruh Karakteristik Pekerjaan Terhadap Kepuasan Kerja dan Komitmen Organisasi Serta Dampaknya Pada Produktivitas Kerja Karyawan. Sosiohumaniora. Vol. 8, No. 2, 143-157.

Faslah, R \& Savitri, M. T (2013). Pengaruh Motivasi dan Disiplin Kerja Terhadap Produktivitas Kerja Pada Karyawan PT. Kabelindo Murni Tbk. Jurnal Pendidikan Ekonomi dan Bisnis (JPEB). Vol.1 No.2. ISSN: 2302-2663

Hackman, J. R. \& Oldham, G.R. (1980). Work Redesign. Reading, MA: AddisonWesley

Hendryadi. (2015). Karakteristik Pekerjaan (Job Characteristics) Literature Reiview. Teori Online Personal Paper. No. 1

Liwarto, I. H., \& Kurniawan, A. (2015). Hubungan Psycap dengan Kinerja Karyawan PT. X Bandung. Jurnal Manajemen Maranatha, 14(2)

Luthans Fred. (2002). The need for and meaning of positive organizational behavior, 
Journal of Organizational Behavior, 23, 695-706

Luthans F, Avolio B, Walumbwa F, Li W. (2005). The psychological capital of Chinese workers: Exploring the relationship with performance. Management and Organization Review, 1, 247-269.

Luthans F, Avey JB, Avolio BJ, Norman S, Combs G. (2006). Psychological capital development: Toward a microintervention. Journal of Organizational Behavior, 27, 387-393.

Luthans, F., Youssef, C.M. \& Avolio, B.J. (2007), Psychological capital: Developing the Human Competitive Edge, Oxford University Press, Oxford.

Telkom dianggap sebagai tempat kerja terbaik di Asia (2018, 5 Mei). Seluler on-line. Di akses pada tanggal 15 Mei 2018 dari https://selular.id/2018/05/ telkomdianggap-sebagai-tempat-kerjaterbaik-di-asia/

Suhariadi, Fendy. (2001). Produktivitas sebagai bentuk perilaku. INSAN Media Psikologi. Vol 3. No 3. 119-137.
Suhariadi, Fendy. (2002). Pengaruh Intelengensi dan Motivasi Terhadap Semangat Penyempurnaan Dalam Membentuk Perilaku Produktif Efisien. Jurnal ANIMA. Vol. 17.

Suhariadi, Fendy. (2005). Productivity as a from of behavior: an alternative effort toward psychological measurements. 6th Industrial \& Organizational Psychology Conference. Australia

Suhariadi, Fendy. (2016) Forming Values Of Productive Behavior, Interntional Journal of Organization Innovation. Vol 8. No 4.

Sumarti, (2012). Pengaruh Kompensasi dan Motivasi Terhadap Perilaku Produktif Karyawan pada PT. Kereta Api, Industrial Research Workshop and National Seminar, ISBN 978-9793541-25-9

Sutaji, D. S. (2014). Terbentuknya Motivasi Kerja dan Perilaku Produktif Karyawan Sebagai Pengaruh dari Iklim Organisasi. POLBAN 